\title{
Assessment of Physico-Chemical Quality of Soil in Rewa District of Madhya Pradesh
}

\section{Arvind Prasad Dwivedi*}

\author{
*Lecturer, Department of chemistry, Govt. Sanjya Gandhi Smrati Auto P.G.College Sidhi M.P.,India.
}

\begin{abstract}
The aim of this study was to examine the physico-chemical properties and heavy metals in soil of Rewa District. Rewa is a town state of Madhya Pradesh, India. Rewa lies between $24^{\circ} 18^{\prime}$ and $25^{\circ} 12^{\prime}$ north latitudes and $81^{\circ} 2^{\prime}$ and $82^{\circ} 18^{\prime}$. Various soil quality parameters were analyzed by using standard procedures. The readings were taken with the help of Atomic Absorption Spectrophotometer (AAS). Iron and Zinc of all the soil samples were below the recommended level (Iron $380 \mathrm{mg} / \mathrm{kg}$ and Zinc $200 \mathrm{mg} / \mathrm{kg}$ ) prescribed by SQGL value.
\end{abstract}

Keywords: Soil Quality, Physico- chemical Parameters, Rewa District, Madhya Pradesh

\section{INTRODUCTION}

Rewa is a town state of Madhya Pradesh, India. Rewa lies between $24^{\circ} 18^{\prime}$ and $25^{\circ} 12^{\prime}$ north latitudes and $81^{\circ} 2^{\prime}$ and $82^{\circ} 18^{\prime}$. It is also known as the land of white tigers. Industries included oilseed milling and cement manufacturing. There are three large cement industries, which are one of the largest in the country. The district is bounded on the north by UP On the east and south east by Sidhi, on the South by Shahdol and on the west by Satna. Metals that have been shown to be essential for plants, that lower forms of animal life and even other mammals, but essentiality for humans has not been convincingly demonstrated. The yield of crop depends on fertility and presence of micro nutrients and heavy metals in the soil ${ }^{[1]}$. Metals are widely found in nature, particularly in various mineral deposits and soil, meaning that they are available to be taken up by plants and animals that serve as food sources for humans. Heavy metals occur naturally in the ecosystem with large variations in concentration. In modern times, anthropogenic sources of heavy metals, i.e. pollution, have been introduced to the ecosystem. Living organisms require varying amounts of heavy metals. Iron, cobalt, copper, manganese, and zing are required by humans. Excessive levels can be damaging to the organism. Other heavy metals such as mercury, plutonium, and lead are toxin metals and their accumulation over time in the bodies of animals can cause serious illness. Certain elements that are normally toxic are, for certain organisms or under certain conditions, beneficial. Heavy metal toxicity can result in damaged or reduced metal and central nervous function, lower energy levels, and damage to blood composition, lungs, kidneys, liver, and other vital organs. Recent studies have shown that chemical used in agriculture, industry households and for personal care are making their way in to the environmental and that many of them are suspected endocrine disruptors ${ }^{[2]}$.

The industries are located very close to human population and clearly indicate decrease in fertility and presence of various metals. The heavy metal soil contamination from mining and smelting creates a wide spectrum of hazards. Adverse environmental impacts from contaminated mining sites include risk to human health, Phytotoxicity, contamination of soil, and eco-toxicity ${ }^{[3]}$. The aim of this study was to examine the physico-chemical properties and heavy metals in soil of Rewa district with a view to establish the contamination status of the soils a result of anthropogenic input. Soil samples were collected from crop land area, residential area and Industrial area in various sampling stations of Rewa district.

\section{Material AND Methods}

\subsection{Sample Collection}

Soil samples were collected from industrial area, Residential area, and Crop field area of Rewa district during the month of March and April 2015. For testing the soil sample were collected in different 
sterile plastic container cans from each station. After collection of the sample the containers were tightly capped and were immediately transported to the laboratory to avoid any unpredictable changes in the physio-chemical characteristics. Sample should be collected in clean and dry containers, and container should be rinsed thoroughly before collection of sample. Stopper the container after collection of the sample. Various soil quality parameters were analyzed by using standard procedures $[4-5]$

\subsection{Digestion of Soil Samples for Heavy Metal Analysis}

Preparation of Soil sample for heavy metal analysis- Sieving of the soil was completed with the help of $0.5 \mathrm{~mm}$ sieves and was dried for 24 hours after drying it was made cool at room temperature. After drying soil was digested with $\mathrm{HNO}_{3}$ and distilled water, the reading were taken with the help of Atomic Absorption Spectrophotometer (AAS).

Table1. Sampling point and its code number

\begin{tabular}{|c|c|c|c|c|}
\hline S.No. & sampling points & Sampling area & $\begin{array}{l}\text { Depth } \\
\text { in } \mathrm{cm} \text {. }\end{array}$ & $\begin{array}{l}\text { Description of sampling } \\
\text { points }\end{array}$ \\
\hline 1 & $\begin{array}{l}\text { Near Ramnanda higher secondary } \\
\text { school Rewa (SC-1) }\end{array}$ & Crop area & $15 \mathrm{~cm}$ & Near Duari village Rewa \\
\hline 2 & Laxmanpur village (SC-2) & Crop area & $15 \mathrm{~cm}$ & $\begin{array}{l}\text { Near junior high school } \\
\text { Laxmanpur rewa }\end{array}$ \\
\hline 3 & $\begin{array}{l}\text { Govt. higher secondary school } \\
\text { Majhgawa (SC-3) }\end{array}$ & Crop area & $15 \mathrm{~cm}$ & $\begin{array}{l}\text { Behind Govt. higher secondary } \\
\text { school Rewa }\end{array}$ \\
\hline 4 & Sagra village (SC-4) & Crop area & $15 \mathrm{~cm}$ & $\begin{array}{l}\text { Front of police station Sagra } \\
\text { Rewa }\end{array}$ \\
\hline 5 & $\begin{array}{l}\text { Near hospital Sagra village, Rewa } \\
\text { (SC-5) }\end{array}$ & Crop area & $15 \mathrm{~cm}$ & Near hospital Sagra, Rewa \\
\hline 6 & $\begin{array}{l}\text { Near Sanskrit college Bichiya Rewa } \\
\text { (SR-1) }\end{array}$ & $\begin{array}{l}\text { Residential } \\
\text { area }\end{array}$ & $5 \mathrm{~cm}$ & Bichiya residential area Rewa \\
\hline 7 & Shilpi plaza Rewa (SR-2) & $\begin{array}{l}\text { Residential } \\
\text { area }\end{array}$ & $5 \mathrm{~cm}$ & Near Pili kothi Rewa \\
\hline 8 & Railway station Rewa (SR-3) & $\begin{array}{l}\text { Residential } \\
\text { area }\end{array}$ & $5 \mathrm{~cm}$ & Near railway station Rewa \\
\hline 9 & Sanjay Gandhi hospital Rewa (SR-4) & $\begin{array}{l}\text { Residential } \\
\text { area }\end{array}$ & $5 \mathrm{~cm}$ & $\begin{array}{l}\text { Near first gate SG hospital } \\
\text { Rewa }\end{array}$ \\
\hline 10 & $\begin{array}{l}\text { Bharat petroleum Padara, Rewa (SR- } \\
\text { 5) }\end{array}$ & $\begin{array}{l}\text { Residential } \\
\text { area }\end{array}$ & $5 \mathrm{~cm}$ & $\begin{array}{l}\text { Road side of Bharat petroleum } \\
\text { Padara, Rewa }\end{array}$ \\
\hline 11 & JP cement plant Rewa (SI-1) & Industrial area & $10 \mathrm{~cm}$ & $\begin{array}{l}\text { Main gate JP cement plant } \\
\text { Rewa }\end{array}$ \\
\hline 12 & $\begin{array}{l}\text { Birla Kevil plant Chorahata, Rewa } \\
\text { (SI-2) }\end{array}$ & $\begin{array}{l}\text { Industrial } \\
\text { area }\end{array}$ & $10 \mathrm{~cm}$ & $\begin{array}{l}\text { Near Vindhya ITI institute } \\
\text { Chorahata,Rewa }\end{array}$ \\
\hline 13 & $\begin{array}{l}\text { Bela cement plant Maddepur, Rewa } \\
\text { (SI-3) }\end{array}$ & Industrial area & $10 \mathrm{~cm}$ & $\begin{array}{l}\text { Near main gate Bela cement } \\
\text { plant Rewa }\end{array}$ \\
\hline 14 & Gun factory Rewa (SI-4) & $\begin{array}{l}\text { Industrial } \\
\text { area }\end{array}$ & $10 \mathrm{~cm}$ & $\begin{array}{l}\text { Front of main gate gun factory } \\
\text { Rewa }\end{array}$ \\
\hline 15 & $\begin{array}{lll}\text { Vindhya telelinks } & \text { Ltd. Navbasta } \\
\text { Rewa (SI-5) } & & \\
\end{array}$ & Industrial area & $10 \mathrm{~cm}$ & $\begin{array}{l}\text { Main gate of Vindhya telelinks } \\
\text { Navbasta Rewa }\end{array}$ \\
\hline
\end{tabular}

Tabel2. Physico -chemical properties of Soil samples collected from different sampling station of Rewa District all the result are shown

\begin{tabular}{|c|c|c|c|c|c|c|c|c|c|c|c|c|c|c|c|c|c|c|}
\hline \multirow[t]{2}{*}{ Parameters } & \multicolumn{5}{|c|}{ Crop and area } & \multicolumn{5}{|c|}{ Residential area } & \multicolumn{5}{|c|}{ Industrial area } & \multirow[t]{2}{*}{ Mean } & \multirow[t]{2}{*}{ S.D } & \multirow[t]{2}{*}{ C.V } \\
\hline & $S C 1$ & $S C 2$ & $S C 3$ & SC4 & SC5 & SRl & $S R 2$ & SR3 & SR4 & SR5 & SII & $S I 2$ & $S I 3$ & SI4 & $S I 5$ & & & \\
\hline sTEMP. ${ }^{\circ} \mathrm{C}$ & 24.0 & 26.0 & 25.0 & 24.0 & 26.2 & 25.0 & 29.1 & 26.0 & 24.0 & 27.0 & 28.0 & 27.2 & 30.5 & 28.2 & 26.5 & 26.447 & 1.935 & 7.316 \\
\hline$P H$ & 7.4 & 7.6 & 6.5 & 7.8 & 7.7 & 6.1 & 7.3 & 7.4 & 8.3 & 8.5 & 7.9 & 8.0 & 8.4 & 6.3 & 7.6 & 7.520 & 0.730 & 9.710 \\
\hline $\begin{array}{c}E C m \\
m h o s / c m\end{array}$ & 0.27 & 0.13 & 0.29 & 0.19 & 0.32 & 0.28 & 0.05 & 0.31 & 0.02 & 0.25 & 0.35 & 0.22 & 0.45 & .33 & 0.25 & 47 & 13 & 1578 \\
\hline $\begin{array}{|ll|}\mathrm{Ni} & \mathrm{mg} / \mathrm{kg} \\
\end{array}$ & 5.9 & ND & 11.3 & 36.5 & ND & 13.7 & 19.8 & 11.5 & 52.4 & 17.2 & 66.5 & 15.2 & 56.9 & 4.7 & 21.5 & .623 & 21.089 & 2.3 \\
\hline $\mathrm{Fe} \mathrm{mg} / \mathrm{kg}$ & 63.5 & 45.1 & 37.4 & 42.3 & 27.5 & 64.2 & 42.4 & 81.4 & 65.8 & 34.2 & 154.0 & 65.3 & 76.0 & 52.5 & 43.2 & 59.653 & 30.5 & 51.192 \\
\hline $\mathrm{Pb} \mathrm{mg/kg}$ & 5.0 & 7.3 & 3.8 & 8.4 & 17.3 & 9.1 & 22.4 & 6.5 & 35.2 & 27.8 & 54.6 & 42.6 & 66.4 & 23.5 & 32.3 & 24.147 & 19.190 & 79.474 \\
\hline $\mathrm{Cu} \mathrm{mg} / \mathrm{kg}$ & 14.2 & ND & 23.2 & 39.4 & ND & 29.6 & 22.8 & 16.1 & 73.6 & 69.5 & 88.9 & 38.2 & 53.0 & 32.6 & 44.6 & 41.977 & 26.139 & 62.27 \\
\hline $\mathrm{Zn} \mathrm{mg} / \mathrm{kg}$ & 2.1 & 4.2 & 5.6 & 7.2 & 5.6 & 8.3 & 6.0 & 3.1 & 7.02 & 9.4 & 6.0 & 8.4 & 15.6 & 4.2 & 7.4 & 6.675 & 3.194 & 47.84 \\
\hline
\end{tabular}


Table3. SQGL Value for soil

\begin{tabular}{|l|l|}
\hline Parameter & SQGL Value in $\mathbf{~} \mathbf{g} / \mathbf{k g}$ \\
\hline $\mathrm{Ni}$ & 50 \\
\hline $\mathrm{Fe}$ & 380 \\
\hline $\mathrm{Pb}$ & 140 \\
\hline $\mathrm{Cu}$ & 63 \\
\hline $\mathrm{Zn}$ & 200 \\
\hline
\end{tabular}

\section{RESUlTS AND DISCUSSION}

In the present study soil samples were collected from Rewa District. Soil samples were subjected for the analysis of physical and chemical parameters, like temperature, $\mathrm{pH}$, electrical conductivity, and heavy metal (Nickel, Iron, Lead, Copper and Zinc). Analyzed samples data were show in table-2 and graphical representations of data were show in figure 1-4. The SQGL values of physico-chemical parameters shown in table-3.

\subsection{Physico-Chemical Analysis}

In the present investigation the temperature ranged between $24^{\circ} \mathrm{C}$ to $30.5^{\circ} \mathrm{C}$, the highest temperature $\left(30.5^{\circ} \mathrm{C}\right)$ was recorded in $\left(\mathrm{SI}_{3}\right)$ Bela cement plant while the lowest value $\left(24^{\circ} \mathrm{C}\right)$ was observed in $\left(\mathrm{SC}_{1}\right)$ Ramnanda higher secondary school Duari Rewa. The $\mathrm{pH}$ of all the soil samples varied from 6.1 to 8.5 , the highest $\mathrm{pH}$ was observed 8.5 at sampling location $\left(\mathrm{SR}_{5}\right)$ Bharat petrolium Rewa and the minimum value $6.1\left(\mathrm{SR}_{1}\right)$ Bichiya areas. The mean value of $\mathrm{pH}$ was the found 7.52 are shown in table-2. Tripathi et al, 2014 ${ }^{[6]}$ Studies of Physico chemical characteristics of soil in Shahdol District of Vindhya platue and reported the temperature was observed to be $28.64{ }^{\circ} \mathrm{C}$ to $42.28{ }^{0} \mathrm{C}$. PH was observed ranged from 6.4 to 8.4. Tripathi et al, $2015^{[7]}$ determined of soil in Sidhi District and reported the $\mathrm{pH}$ concentration of soil is 5.6 to 8.4. The electrical conductivity of the range from 0.02 to $0.45 \mathrm{~m}$.mhos $\mathrm{cm}^{-1}$, the highest electrical conductivity was recorded 0.45 in $\left(\mathrm{SI}_{3}\right)$ Bela cement plant. Mandal et al, $2010^{[8]}$ studied Nagpur soil and recorded EC 0.21 to $0.49 \mathrm{mhos} / \mathrm{cm}$.

\subsection{Heavy Metal}

The heavy metal concentration in the soil samples of Rewa district with their means, standard deviations and coefficient variation are presented in table-2 Nickel content was found range from 4.7 to $66.5 \mathrm{mg} / \mathrm{kg}$. The highest $(66.5 \mathrm{mg} / \mathrm{kg})$ nickel was observed in $\left(\mathrm{SI}_{1}\right) \mathrm{J} \mathrm{P}$ cement plant while the lowest $(4.7 \mathrm{mg} / \mathrm{kg})$ nickel was observed in $\left(\mathrm{SI}_{4}\right)$ Gun factory Rewa. Iron concentration was observed range between 27.5 to $154.0 \mathrm{mg} / \mathrm{kg}$. Tripathi et al, $2015{ }^{[9]}$ Studied the heavy metal analysis of soil sample collected from around Satna district and reported Iron content range between 59.7 to 157.2 $\mathrm{mg} / \mathrm{kg}$. Lead concentration range between 3.8 to $66.4 \mathrm{mg} / \mathrm{kg}$ the highest lead was observed in $\left(\mathrm{SI}_{3}\right)$ Bela cement plant area. All Lead content of the entire sample were below the recommended level Govil et al, $20088^{[10]}$ studied contamination of katedan industrial of Hyderabad and reported the lead content $0.5 \mathrm{mg} / \mathrm{kg}$ to $140 \mathrm{mg} / \mathrm{kg}$. Cupper concentration was found range between 14.2 to $88.9 \mathrm{mg} / \mathrm{kg}$. Values of Cupper content at sampling location $\left(\mathrm{SI}_{1}\right) \mathrm{J} \mathrm{P}$ cement plant $(88.9 \mathrm{mg} / \mathrm{kg}),\left(\mathrm{SR}_{4}\right)$ near Sanjay Gandhi hospital (73.6 mg $/ \mathrm{kg}$ ) and (SR5) Bharat petrolium Padara Rewa $(69.5 \mathrm{mg} / \mathrm{kg}$ ) are higher than the SQGL recommended level value as $63 \mathrm{mg} / \mathrm{kg}$. Kumar et al $2012^{[11]}$ worked on heavy metal pollution assessment in industrial area soil of Mysore city and reported copper concentration ranged from 16.0-20.3 mg/kg. Zinc concentration range between 2.1 to $15.6 \mathrm{mg} / \mathrm{kg}$. The highest zinc (15.6) was observed in $\left(\mathrm{SI}_{3}\right)$ Bela cement plant while the lowest value of zinc was observed (2.1) in $\left(\mathrm{SC}_{1}\right)$ Duari Rewa. Chahal et al, $2014{ }^{[12]}$ studied evaluation of heavy metals contamination and its genotoxicity in agricultural soil of Amritsar, Punjab, India reported the zinc content range from 73$320 \mathrm{mg} / \mathrm{kg}$.

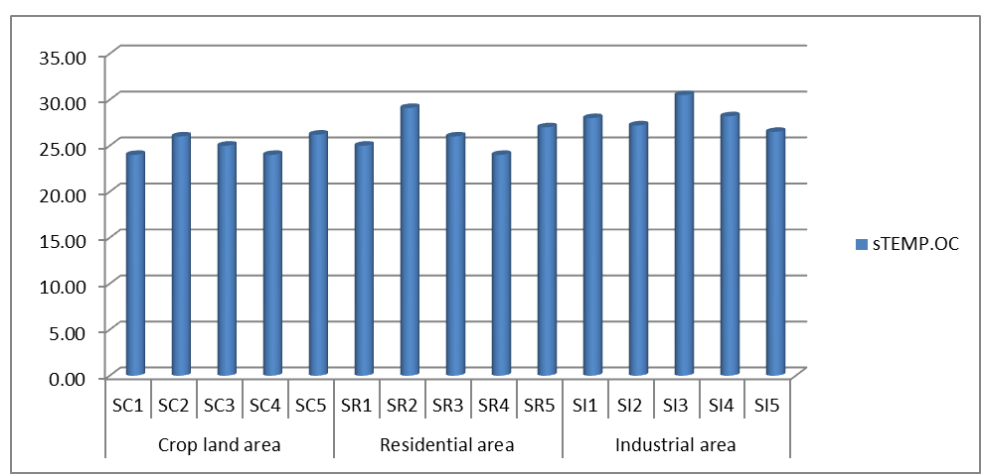

Fig1. Temperature in soil of Rewa District 


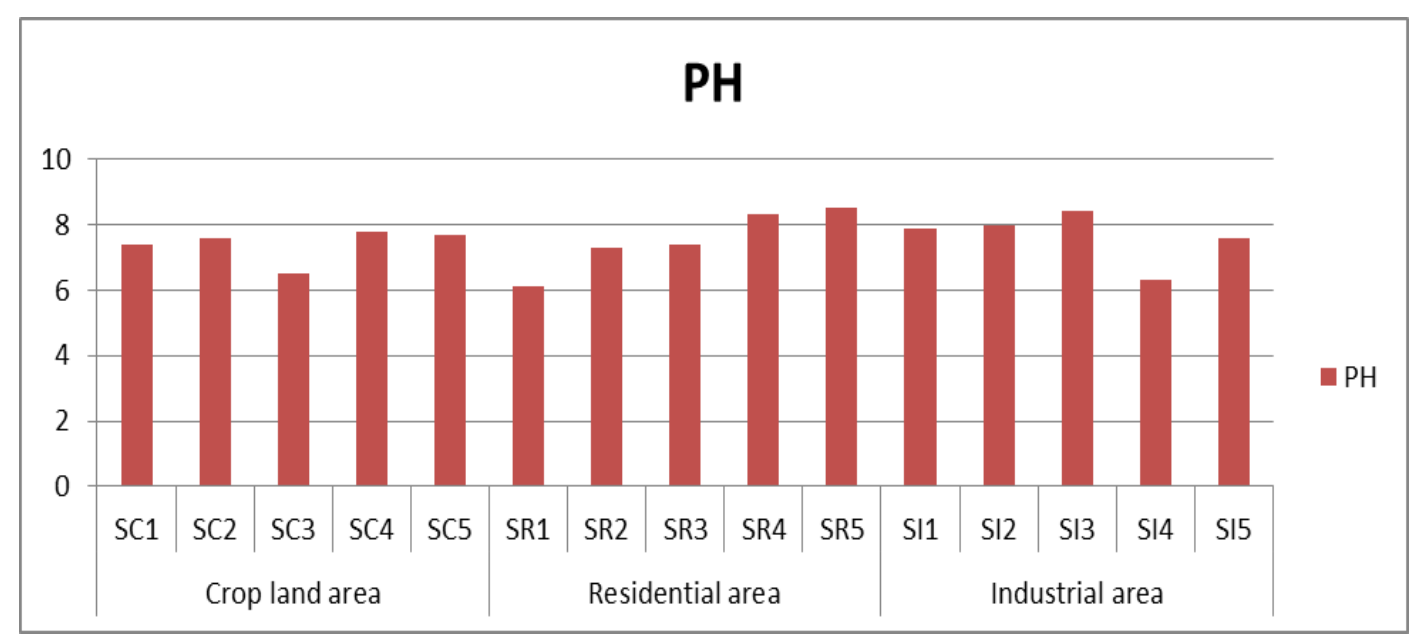

Fig2. $p H$ concentration in soil of Rewa District

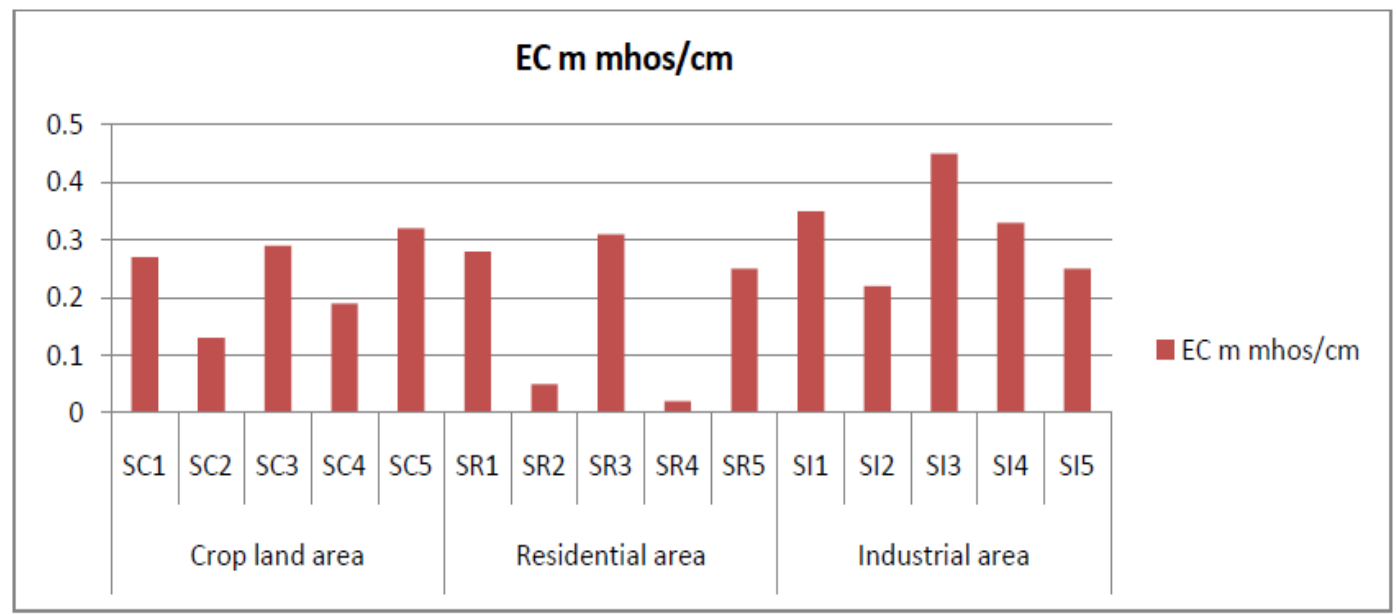

Fig3. EC presented in soil of Rewa District

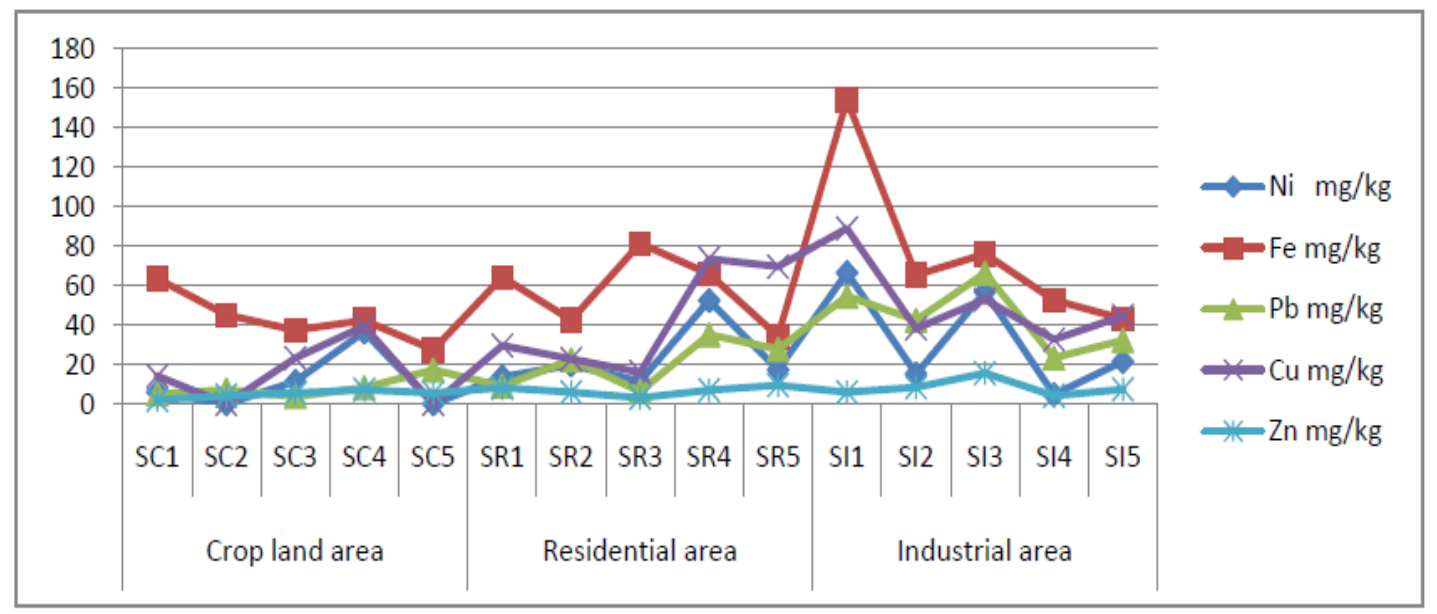

Fig4. Metal content in soil of Rewa District

\section{CONClusion}

Fifteen soil samples were collected from three different area of Rewa District. The values ranges of different parameters temperature (22 to28 c) pH-7.60 to8.80, EC 0.69 to 3.20, Fe- 27.5 to $154.0 \mathrm{mg} / \mathrm{kg}$, $\mathrm{Cu}-14.2$ to $88.9 \mathrm{mg} / \mathrm{kg}$ and $\mathrm{Zn} 2.1$ to $15.6 \mathrm{mg} / \mathrm{kg}$ were found in soil of Rewa district. Iron and Zinc of all the soil samples were below the recommended level (Iron $380 \mathrm{mg} / \mathrm{kg}$ and Zinc $200 \mathrm{mg} / \mathrm{kg}$ ) prescribed by SQGL value. Nickel and Copper values were observed at sampling station SI1 (J.P. cement plant) and SR4 (Sanjay Gandhi Hospital) are higher than the SQGL value. The results confirm the sources of contamination to be anthropogenic from Industrial, urban and other anthropogenic activities in Rewa soil which has lead to the contamination of soil in the study area. 


\section{REFERENCES}

[1] A.P. Dwivedi, I.P. Tripathi and M. Suresh Kumar, Assessment of soil and Ground water Quality in Rewa District of Vindhyan Plateau (India), Journal Environ. Science \& Engg. 2013, 55, (1), 51-64.

[2] Al-Omran, A.M., A.S.Sheta, A.M. Falatah \& Al-Harbi, A.R., Effect of drip Irrigation on squash (Cucurbita Pepo) Yield and water use Efficiency in sandy calcareous soils Amended with clay deposi, Agricultural Water Management., 2005,73, 43-55.

[3] M. Anju, D. K. Banerjee. Multivariate Statistical Analysis of Heavy Metals in Soils of a $\mathrm{Pb}-\mathrm{Zn}$ Mining Area, India. Int. Environ Monit Assess, DOI 10. 1007/s10661-011-2255-8, 2011.

[4] A. K. Dc, Environmental chemistry, New Age International Publisher, New Dilhi, ${ }^{\text {th }}$ Edition 1982.

[5] C.S. Piper, A Laboratory of Methods for the Examination of soil and the Determination of the Inorganic Constituents of Plant. Original Edition- Printed in India. Scientific Publisher Jodhpur (Raj.) India 1992.

[6] Indra Prasad Tripathi, Arvind Prasad Dwivedi, M.Suresh Kumar, Physico-Chemical Characteristic of Soil in Shahdol District of Vindhya Platue, Journal of Applicable Chemistry, 2014, 3 (3) , 1155-1164.

[7] Indra Prasad Tripathi and Arvind Prasad Dwivedi, Multivariate analysis of soil and Ground Water Quality in Sidhi District of Vindhya Plateau, Journal of applicable Chemistry, 2015,4 (1) ,178-203.

[8] D.K. Mandal, Deepti Agarkar and N.C. Khandare . Rationale of International land Evaluation Methods under aberrant Climatic Conditions in shrink- swell soil of Indian Semiarid Tropics. Journal of Indian Society of soil Science, 2010, 58 (2), 141-146.

[9] Indra Prasad Tripathi, Arvind Prasad Dwivedi, Heavy Metal Analysis of soil Samples Collected from in and Around Satna, International Journal of Information Research and Review, 2015, 2 (3), 516-520.

[10] P.K. Govil, J.E. Sorlie, N.N. Murthy, D. Sujatha, D. Reddy G.L.N., Rodolph-lund kim, Krishna, A.K. and K. Rama Mohan, Soil Contamination of Heavy Metals in the Katedan Industrial development Area, Hyderabad, India; Journal of Environment Assess. 2008,140,313-323.

[11] K.K. Shivakumar and M.S. Dheenadayalan, Distribution of Heavy Metals Profile in water and soil System at Amaravati River Basin of Karur Tamil Nadu , Journal of IJEP , 2012,32(2):152157.

[12] Vanita Chahal, Piar Chand, Avinash Nagpal, Jatinder Kaur Katnoria and Yogesh Pakade, Evaluation of Heavy Metals Contamination and its Genotoxicity in Agricultural soil of Amritsar, Panjab India, International Journal of Research in Chemistry and Environment, 2014,4(4) 20-28. 